\title{
ANALISIS KETERAMPILAN BERBICARA SISWA KELAS V PADA MATA PELAJARAN BAHASA INDONESIA
}

\author{
Kadek Dwi Padmawati ${ }^{1}$, Ni Wayan Arini $^{2}$, Kadek Yudiana ${ }^{3}$ \\ 1,2,3 Jurusan Pendidikan Guru Sekolah Dasar, FIP \\ Universitas Pendidikan Ganesha \\ Singaraja, Indonesia \\ email : dwipadmawati5@gmail.com1, wayan.arini@undiksha.ac.id², \\ kadek.yudiana@undiksha.ac.id ${ }^{3}$
}

\begin{abstract}
Abstrak
Penelitian ini bertujuan untuk mendeskripsikan keterampilan berbicara siswa kelas $\mathrm{V}$ pada pelajaran bahasa Indonesia di SD Negari 4 Temukus dan mendeskripsikan faktor-faktor yang memengaruhi keterampilan berbicara siswa kelas $\mathrm{V}$ pada pelajaran bahasa Indonesia di SDN 4 Temukus tahun pelajaran 2017/2018. Jenis penelitian ini adalah deskriptif kualitatif. Penelitian ini dilaksanakan di kelas V SDN 4 Temukus Kecamatan Banjar Kabupaten Buleleng tahun pelajaran 2017/2018 karena dengan pertimbangan sekolah tersebut terdapat masalah terkait keterampilan berbicara siswa kelas $\mathrm{V}$ serta kurangnya perhatian guru terhadap keterampilan berbicara. Analisis data dilakukan setelah dilakukan pengumpulan data sesuai dengan tujuan yang ingin dicapai. Pengumpulan data ini menggunakan instrument pedoman wawancara dan lembar observasi berupa rubrik penilaian. Dalam penelitian ini, peneliti menggunakan teknik analisis deskriptif kualitatif dan kuantitatif. Hasil penelitian menunjukan bahwa data peresentase hasil observasi keterampilan berbicara pada mata pelajaran bahasa Indonesia siswa kelas V di SD Negeri 4 Temukus adalah $64 \%$. Berdasarkan standar penilaian acuan skala lima hasilnya termasuk ke dalam kategori rendah. Deskripsi faktor-faktor yang memengaruhi keterampilan berbicara pada mata pelajaran bahasa Indonesia siswa kelas V di SD Negeri 4 Temukus. Pertama, faktor fisik yaitu alat ucap untuk menghasilkan bunyi bahasa. Kedua, faktor psikologis dapat mempengaruhi terhadap kelancaran berbicara. Ketiga, faktor neurologis yaitu jaringan saraf yang menghubungkan otak kecil dengan mulut, telinga dan organ tubuh lain yang ikut dalam aktivitas berbicara. Keempat, faktor semantik yang berhubungan dengan makna. Kelima, faktor linguistik yang berkaitan dengan struktur bahasa.
\end{abstract}

Kata kunci: keterampilan berbicara, pelajaran bahasa indonesia

\section{Abstract}

This study aimed at describing Indonesian language speaking skill and factors influencing the Indonesian language speaking skill of fifth graders in SDN 4 Temukus academic year 2017/2018. This study was a descriptive qualitative study. The object of the study was fifth graders of SDN 4 Temukus, Banjar District, Buleleng Regency academic year 2017/2018. It was due to the problems in speaking skill and low awareness of teacher towards speaking skill. Data analysis was done based on the purpose of the study. The data were collected through questionnaire and observation sheets in the form of assessment rubric. The data were analysed qualitatively and quantitatively. The results of the study show that percentage of observation result of Indonesian language speaking skill in fifth grade of SDN 4 Temukus was $64 \%$. Based on the standard of assessment, it is categorised into low level. Further, the factors influencing the Indonesian language speaking skill in fifth grade of SDN 4 Temukus are; First, physical factor namely speech organs; Second, psychological factor; Third, neurological factor, it is nerve system connecting cerebellum to mouth, ears, and other body organs related to the production of sound; Fourth semantic factor, it is related to meaning; and Fifth, linguistic factor, it is related to language structure.

Keywords: Indonesian language subject, speaking skill 


\section{Pendahuluan}

Pendidikan merupakan suatu proses yang diperlukan untuk mendapatkan keseimbangan dan kesempurnaan dalam perkembangan individu maupun masyarakat. Penekanan pendidikan dibanding dengan pengajaran terletak pada pembentukan kesadaran dan kepribadian individu atau masyarakat di samping transfer ilmu dan keahlian. Dengan proses semacam ini suatu bangsa atau negara dapat mewariskan nilai-nilai keagamaan, kebudayaan, pemikiran dan keahlian kepada generasi berikutnya, sehingga mereka betul-betul siap menyongsong masa depan kehidupan bangsa dan negara yang lebih cerah. Pendidikan juga merupakan sebuah aktifitas yang memiliki maksud atau tujuan tertentu yang diarahkan untuk mengembangkan potensi yang dimiliki manusia baik sebagai manusia ataupun sebagai masyarakat dengan sepenuhnya (Nurkholis, 2013).

Pendidikan merupakan kegiatan yang kompleks, dan meliputi berbagai komponen yang berkaitan erat satu sama lain. Oleh sebab itu, apabila pendidikan ingin dilaksanakan secara terencana dan teratur, maka berbagai faktor yang terlibat dalam pendidikan harus dipahami terlebih dahulu. Berbagai komponen dalam sistem pendidikan, baik secara mikro maupun dalam kajian makro perlu dikenali secara mendalam sehingga komponen-komponen tersebut dapat difungsikan dan dikembangkan guna mengoptimalkan garapan pendidikan tersebut ke arah pencapaian tujuan pendidikan yang ditetapkan (Dinn Wahyudi dkk, 2006) (Sutrisno ,2016)

Pasal 1 UU SISDIKNAS no. 20 tahun 2003 disebutkan bahwa Sistem Pendidikan Nasional adalah keseluruhan komponen pendidikan yang saling terkait secara terpadu untuk mencapai tujuan pendidikan nasional. Berangkat dari bunyi pasal ini dapat diketahui bahwa pendidikan adalah sistem yang merupakan suatu totalitas struktur yang terdiri dari komponen yang saling terkait dan secara bersama menuju kepada tercapainya tujuan (Soetarno, 2003: 2). Adapun komponen-komponen dalam pendidikan nasional antara lain adalah lingkungan, sarana-prasarana, sumberdaya, dan masyarakat. Komponen-komponen tersebut bekerja secara bersama-sama, saling terkait dan mendukung dalam mencapai tujuan pendidikan (Munirah, 2015).

Pendidikan bahasa Indonesia merupakan salah satu aspek penting yang perlu diajarkan kepada para siswa di sekolah, tidak heran apabila mata pelajaran ini kemudian diberikan sejak masih di bangku SD hingga lulus SMA. Asiah (2015:22) menyatakan, "Bahasa memiliki peran sentral dalam perkembangan intelektual, sosial, dan emosional peserta didik dan merupakan penunjang keberhasilan dalam mempelajari semua bidang studi". Oleh sebab itu, dalam proses pembelajaran diharapkan siswa mampu menguasai, memahami dan dapat mengimplementasikan keterampilan berbahasa dengan baik dan benar untuk menunjang keberhasilan dalam proses pembelajaran.

Pembelajaran bahasa Indonesia di SD adalah sebagai wadah untuk mengembangkan kemampuan siswa dalam menggunakan bahasa sesuai dengan fungsi bahasa, terutama sebagai alat komunikasi. Pembelajaran bahasa Indonesia diharapkan dapat meningkatkan kemampuan siswa dalam berkomunikasi secara lisan ataupun tertulis. Pembelajaran bahasa Indonesia akan berlangsung secara efektif dan efisien apabila guru dalam penyampaian materi pembelajaran disampaikan dengan cara yang menyenangkan. Dalam kegiatan proses pembelajaran bahasa Indonesia diharapkan dalam penyampaian materi mampu mengundang rasa ingin tahu siswa dalam kegiatan pembelajaran, menciptakan pembelajaran yang menantang bagi siswa untuk belajar dan mampu mengaktifkan mental, fisik dan psikis siswa. Dengan demikian proses pembelajaran yang seperti itu akan mampu meningkatkan kreativitas siswa yang berdampak pada hasil belajarnya yang mengalami peningkatan.

Pembelajaran bahasa Indonesia di SD diarahkan untuk mengembangkan kemampuan siswa untuk memahami dan menggunakan bahasa sebagai alat komunikasi secara efektif, baik secara lisan maupun tulis (Wibawa, 2016). Selain itu pembelajaran di SD juga bertujuan untuk mengembangkan kemampuan bernalar, berkomunikasi dan mengungkapkan pikiran, perasaan serta membina persatuan dan kesatuan bangsa. Wardana (2014) menjelaskan, ruang lingkup muatan materi bahasa Indonesia mencangkup empat aspek keterampilan berbahasa, yakni 
keterampilan berbicara, keterampilan menyimak, keterampilan membaca dan keterampilan menulis. Keterampilan berbahasa mempunyai keterkaitan antara satu dengan yang lainnya yang berurutan dan teratur, dimulai dengan belajar menyimak atau mendengarkan bahasa, kemudian berbicara, sesudah itu belajar membaca dan menulis. Keempat hal tersebut merupakan satu kesatuan dan tidak dapat dipisahkan antara satu dengan yang lainnya, keempat keterampilan tersebut diperoleh secara alamiah oleh manusia sejak dari kecilnya sampai mendapat pendidikan. Dalam dunia pendidikan, keempat keterampilan berbahasa tersebut wajib dikuasai oleh siswa. Dengan demikian, pembelajaran keterampilan berbahasa di sekolah tidak hanya menekankan pada teori, tetapi siswa dituntut untuk mampu menggunakan bahasa sesuai dengan fungsinya, yaitu sebagai alat untuk berkomunikasi.

Salah satu keterampilan yang penting dipelajari oleh siswa adalah keterampilan berbicara. Berbicara merupakan salah satu sarana untuk menyampaikan sesuatu kepada orang lain dengan tujuan-tujuan tertentu. Memiliki keterampilan berbicara yang baik mampu memudahkan penyimak dan pendengar untuk memahami hal-hal yang disampaikan oleh seorang pembicara. Tarigan dalam Haryadi (1996/1997:54) menyatakan bahwa "berbicara adalah salah satu keterampilan berbahasa sebagai kemampuan mengucapkan bunyi-bunyi artikulasi atau kata-kata untuk mengekspresikan, menyatakan serta mengungkapkan pendapat atau pikiran dan perasaan kepada seseorang atau kelompok secara lisan, baik secara berhadapan ataupun dengan jarak jauh". Berbicara sebagai salah satu aspek keterampilan berbahasa memiliki keterkaitan erat dengan aspek keterampilan berbahasa lainnya, yaitu antara berbicara dengan menyimak, berbicara dengan menulis, dan berbicara dengan membaca.

Keterampilan berbicara sesuai dengan kompetensi umum yaitu mengungkapkan gagasan dan perasaan, berdialog, menyampaikan pesan, menjelaskan dan bermain peran. Keterampilan berbicara merupakan keterampilan berbahasa lisan yang dimiliki oleh semua orang yang bermaksud untuk menyampaikan pesan kepada orang lain. Norton dalam Arini dkk (2006:53) menyatakan "keterampilan anak dalam berbicara merupakan hal yang mendasar untuk keberhasilannya dalam setiap bagian kehidupan, baik di sekolah maupun di rumah". Tiap manusia dituntut terampil berkomunikasi, terampil menyatakan pikiran, gagasan, ide, dan perasaan. Terampil menangkap informasi-informasi yang didapat, dan terampil pula menyampaikan informasi-informasi yang diterimanya.

Dari hasil wawancara dengan guru yang dilakukan pada tanggal 21 Desembar 2017 diperoleh informasi bahwa, 1) Ada beberapa siswa yang memiliki keterampilan berbicara yang kurang baik, hal tersebut dibuktikan dengan adanya beberapa siswa yang masih ragu-ragu dan tidak percaya diri dalam berbicara. 2) Guru belum maksimal meggunakan model pembelajaran yang sesuai dan menyenangkan dalam proses pembelajaran, hal tersebut disebabkan karena guru cenderung menggunakan pembelajaran konvensional dalam proses pembelajaran. Sedangkan dari observasi diperoleh beberapa informasi. 1) kurangnya keaktifkan siswa untuk mau berbicara dalam proses pembelajaran, 2) beberapa siswa dalam berbicara kurang lancar dan kurang dapat dipahami, 3) suara siswa saat berbicara kurang jelas, 4) pembelajaran yang masih berpusat pada guru, siswa lebih banyak diam dan mengerjakan tugas yang diberikan guru. Pada pembelajaran bahasa Indonesia masih banyak siswa yang kurang mampu menyampaikan ide dan gagasannya melalui komunikasi secara lisan dalam situasi formal serta belum mencapai ketuntasan dalam keterampilan berbicara. Hal ini dikarenakan adanya siswa yang kurang percaya diri dalam berbicara, sehingga dalam proses pembelajaran siswa menjadi pasif. Melalui menguasai keterampilan berbicara, peserta didik akan mampu mengekspresikan pikiran dan perasaannya secara cerdas sesuai konteks dan situasi saat sedang berbicara.

Keterampilan berbicara harus dikuasai oleh para siswa SD karena keterampilan ini secara langsung berkaitan dengan seluruh proses belajar siswa di Sekolah Dasar. Keberhasilan belajar siswa dalam mengikuti proses pembelajaran di sekolah sangat ditentukan oleh penguasaan kemampuan berbicara mereka. Siswa yang tidak mampu berbicara dengan baik dan benar akan mengalami kesulitan dalam mengikuti kegiatan pembelajaran untuk semua mata pelajaran. Keterampilan berbicara secara efektif sangatlah penting dalam segala bentuk interaksi antar manusia didalam suatu masyarakat. 
Berdasarkan permasalahan yang ditemukan, guru perlu memberikan proses pembelajaran yang lebih baik untuk melatih keterampilan berbicara siswa. Dengan demikian keterampilan berbicara memang sangat penting untuk dilatihkan sebagai bekal bagi anak-anak untuk dapat berkomunikasi dengan baik di lingkungannya sehingga dapat menyesuaikan diri dengan lingkungan. Berdasarkan pengamatan langsung dilapangan peneliti beranggapan sangat menarik untuk diteliti lebih lanjut tentang "Analisis Keterampilan Berbicara Siswa Kelas $\checkmark$ pada Mata Pelajaran Bahasa Indonesia di SDN 4 Temukus Kecamatan Banjar Tahun Pelajaran 2017/2018". Dengan dengan melakukan analisis keterampilan berbicara siswa, guru dapat memberikan tindak lanjut bagi siswa yang memiliki keterampilan berbicara yang kurang. Penelitian ini bertujuan untuk men getahui deskripsi tentang keterampilan berbicara siswa dalam proses pembelajaran serta faktor-faktor yang memengaruhi keterampilan berbicara siswa kelas V.

\section{Metode}

Penelitian ini dilaksanakan di kelas V SDN 4 Temukus Kecamatan Banjar Kabupaten Buleleng tahun ajaran 2017/2018. SD Negeri 4 Temukus dipilih karena dengan pertimbangan sekolah tersebut terdapat masalah terkait keterampilan berbicara siswa kelas $\mathrm{V}$ serta kurangnya perhatian guru terhadap keterampilan berbicara.

Dalam penelitian ini terdapat prosedur penelitian yang akan dilakukan oleh peneliti. Prosedur dari penelitian ini meliputi tahapan persiapan, tahap pelaksanaan di lapangan, tahap pasca lapangan.

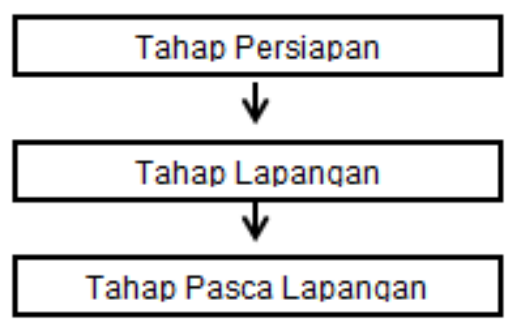

\section{Gambar 1. Diagram Alur Rencana Penelitian}

Jenis data yang dikumpulkan dalam penelitian ini adalah data kuantitatif yang diperoleh melalui observasi sebagai instrumen penelitian dan data kualitatif yang diperoleh dari hasil wawancara. Sumber data atau subjek penelitian dalam penelitian ini adalah siswa kelas $\mathrm{V}$ di SD Negeri 4 Temukus yang berjumlah 22 responden. Penentuan informan dalam penelitian ini diperoleh dari hasil observasi awal sebelum melakukan penelitian dan menggunakan prosedur purposive yaitu dipilih dengaan pertimbangan dan tujuan tertentu yang terkait dengan penelitian.

Tabel 1. Data Penelitian, Instrument, dan Subjek Penelitian yang digunakan

\begin{tabular}{lccc}
\hline \multicolumn{1}{c}{ Data Penelitian } & Metode & Instrumen & Subjek \\
\hline $\begin{array}{l}\text { Keterampilan berbicara pada mata } \\
\text { pelajaran bahasa Indonesia siswa } \\
\text { kelas V }\end{array}$ & Observasi & Lembar Observasi & Siswa \\
\hline $\begin{array}{l}\text { Faktor-faktor yang memengaruhi } \\
\text { keterampilan berbicara pada pelajaran } \\
\text { bahasa Indonesia siswa kelas V }\end{array}$ & Wawancara & Pedoman wawancara & Siswa \\
\hline
\end{tabular}

Metode pengumpulam data merupakan langkah paling strategis dalam penelitian, karena tujuan utama dari penelitian ini adalah mengumpulkan data. Metode pengumpulan data dalam 
penelitian ini untuk mengetahui keterampilan berbicara siswa yaitu dengan menggunakan metode observasi dan metode wawancara. Kedua metode tersebut digunakan secara alami tanpa memberikan perlakuan khusus terlebih dahulu

Tabel 2. Indikator Keterampilan Berbicara

\begin{tabular}{lll}
\hline No & \multicolumn{1}{c}{ Aspek Penilaian } & \multicolumn{1}{c}{ Deskripsi } \\
\hline 1 & Lafal & Siswa menyampaikan informasi dengan Lafal yang jelas \\
2 & Intonasi & Siswa menyampaikan informasi dengan Intonasi yang \\
3 & Kelancaran & tepat \\
4 & Ekspresi & Siswa lancar dalam penyampaikan informasi \\
& Ketepatan isi & Siswa menggunakan ekspresi dalam penyampaian \\
& pembicaraan & informasi \\
\hline
\end{tabular}

Data yang dikumpulkan dalam penelitian ini adalah data keterampilan berbicara siswa. Sumber data dalam penelitian ini adalah siswa kelas V semester II SD Negeri 4 Temukus. Data keterampilan berbicara siswa dikumpulkan dengan metode non tes yaitu dengan menggunakan lembar observasi dan pedoman wawancara.

Analisis data dilakukan setelah dilakukan pengumpulan data sesuai dengan tujuan yang ingin dicapai. Data yang dianalisis adalah data yang dihasilkan wawancara dan observasi. Dalam penelitian ini, peneliti menggunakan teknik analisis deskriptif kualitatif dan kuantitatif. Teknik analisis deskriptif kualitatif adalah suatu teknik menganalisis data dengan cara menginterpretasikan data yang diperoleh dengan kata-kata. Teknik analisis kualitatif ini dilakukan untuk menggambarkan fakta dan sarana cerita mengenai hasil wawancara dengan siswa dan guru mengenai faktor-faktor yang memengaruhi keterampilan berbicara.

Sedangkan analisis deskriptif kuantitatif digunakan untuk menggambarkan keterampilan berbicara pada mata pelajaran bahasa Indonesia. Untuk mengetahui Analisis data keterampilan berbicara siswa pada mata pelajaran bahasa Indonesia menggunakan data lembar observasi yang mengacu pada indikator keterampilan berbicara. Tabel Standar penilaian yang digunakan mengacu pada pedoman penilaian acuan atau PAP Skala lima dengan kriteria sebagai berikut.

Tabel 3.Pedoman Konvensional PAP Skala Lima Tentang Hasil Observasi Keterampilan Berbicara

\begin{tabular}{cc}
\hline Persentase (\%) & Kategori \\
\hline $90-100$ & Sangat tinggi \\
$80-89$ & Tinggi \\
$65-79$ & Sedang \\
$55-64$ & Rendah \\
$0-54$ & Sangat rendah \\
\hline
\end{tabular}

\section{Hasil Dan Pembahasan}

Deskripsi dan analisis data penelitian ini menggambarkan data yang diperoleh melalui analisis lembar observasi keterampilan berbicara siswa dalam pembelajaran bahasa Indonesia yang diamati siswa kelas V di SD Negeri 4 Temukus yang terdiri dari 22 Responden. Analisis observasi keterampilan berbicara siswa dalam pelajaran bahasa Indonesia dilakukan secara deskriptif bertujuan untuk menggambarkan keterampilan berbicara siswa kelas V di SD Negeri 4 Temukus, Kecamatan Banjar, Kabupaten Buleleng tahun pelajaran 2017/2018. Deskripsi data dari keterampilan berbicara siswa kelas V di SD Negeri 4 Temukus secara keseluruhan 
terlihat baik. Berikut deskripsi prosedur penelitian yang dilakukan untuk mengetahui data keterampilan berbicara siswa kelas V di SD Negeri 4 Temukus pada setiap indikator keterampilan berbicara dalam pelajaran bahasa Indonesia.

Tahap pertama adalah persiapan, kegiatan ini merupakan tahap awal yang dilakukan peneliti untuk mengetahui kondisi sekolah dan sebagai tahap awal perkenalan peneliti dengan guru yang mengajar di lingkungan sekolah. Kegiatan persiapan ini dilakukan tanggal 21 Desember 2018. Peneliti datang ke sekolah dan bertemu dengan Bapak Gede Artika, S Ag. Selaku kepala sekolah SD Negeri 4 Temukus. Pada kegiatan persiapan ini peneliti sekaligus membawa surat untuk melakukan penelitian di sekolah ini dan disambut dengan sangat baik. Setelah berbincang dengan kepala sekolah dan peneliti menyampaikan tujuan penelitian yang akan dilaksanakan, kepala sekolah mengantarkan peneliti untuk beremu dengan guru kelas $\mathrm{V}$, yakni Bapak Kandel. Kepala sekolah menyerahkan peneliti kepada guru kelas V, karena subjek penelitian adalah siswa kelas $\mathrm{V}$ dan mengarahkan peneliti untuk berdiskusi lebih lanjut dengan guru kelas $\mathrm{V}$ agar penelitian yang dilaksanakan sesuai dengan rencana yang telah dijadwalkan. Pada tahap awal ini sekaligus peneliti melakukan wawancara pertama dengan guru kelas $\mathrm{V}$ mengenai aktivitas siswa dalam mengikuti pembelajaran bahasa Indonesia terutama pada keterampilan berbicara siswa. Beliau banyak bercerita mengenai pengalamannya mengajar bahasa Indonesia terutama pada keterampilan berbicara siswa dan menyampaikan beberapa permasalah yang terkadang terjadi di dalam kelas.

Tahap kedua adalah pelaksanaan, penelitian Tahap pelaksanaan penelitian ini terdiri dari 5 kali peneliti mengikuti pembelajaran di dalam kelas dan 2 kali pertemuan melakukan wawancara dengan siswa. Penelitian dimulai tanggal 23 Maret 2018 sampai tanggal 10 April 2018. Peneliti hanya dapat mengikuti pembelajaran di hari Senin dan Jumat setiap jam pembelajaran ke 4 dan 5, pada proses pembelajaran di dalam kelas peneliti melakukan observasi kegiatan siswa dalam proses pembelajaran bahasa Indonesia khususnya pada keterampilan berbicara siswa, peneliti juga melakukan wawancara dengan siswa untuk mendapatkan informasi mengenai faktor-faktor yang memengaruhi keterampilan berbicara siswa. Dalam kegiatan observasi, peneliti melihat keaktifan dan antusias siswa dalam mengikuti pembelajaran, menjawab pertanyan yang diberikan oleh guru bahkan ada beberapa siswa yang aktif menyampaikan pendapatnya.

Tahap ketiga adalah tahap analisis data. Data hasil skor lembar observasi keterampilan berbicara yang diperoleh dengan penggabungan skor indikator-indikator keterampilan berbicara, data tersebut diperoleh melalui analisis lembar observasi yang terdiri dari 22 orang siswa. Setiap indikator diukur dengan skor rentangan penilaian yang tertinggi adalah 5 dan skor terendah yaitu 1, secara keseluruhan terdapat 5 indikator keterampilan berbicara yang akan diobservasi. Data keterampilan berbicara siswa diperoleh dengan menggabungkan indikator keterampilan berbicara yang terdiri dari indikator lafal, intonasi, kelancaran, ekspresi dan ketepatan isi. Skor maksimal ideal yang diperoleh adalah 25 dan skor minimal ideal adalah 5. Hasil observasi keterampilan berbicara siswa kelas $\mathrm{V}$ pada mata pembelajaran bahasa Indonesia di SD Negeri 4 Temukus ditentukan dengan cara menghitung skor rata-rata yang dikonversikan ke dalam kriteria rata-rata ideal (Xi) dan standar deviasi ideal (SDi), Pedoman konversi disajikan dalam Tabel 4 berikut.

Tabel 4. Pedoman Konversi Rata-rata Ideal dan Standar Deviasi ideal Skala Lima Keterampilan Berbicara

\begin{tabular}{cc}
\hline Rentangan Skor & Kategori \\
\hline $20 \leq x \leq 25$ & Sangat Tinggi \\
$16,67 \leq x<20$ & Tinggi \\
$13,33 \leq x<16,67$ & Sedang \\
$10 \leq x<13,33$ & Rendah \\
$5 \leq x<10$ & Sangat Rendah \\
\hline
\end{tabular}


Berdasarkan hasil konversi, skor rata-rata keterampilan berbicara siswa kelas $\mathrm{V}$ pada mata pembelajaran bahasa Indonesia di SD Negeri 4 Temukus diperoleh rata-rata $(X)=16$, yang termasuk kategori sedang. Hasil perhitungan konversi rata-rata keterampilan berbicara siswa kelas $\mathrm{V}$.

Skor keterampilan berbicara yang diperoleh setiap siswa kemudian dikonversi pada tiaptiap kategori skor keterampilan berbicara dan dianalisis dengan deskriptif persentase. Hasil peresentase menunjukan tingkat keberhasilan siswa dalam berbicara. Berikut ini disajikan hasil analisis keterampilan berbicara siswa dalam bentuk persentase.

Tabel 5. Distribusi Frekuensi Data Keterampilan Berbicara Siswa Kelas V pada Mata Pembelajaran Bahasa Indonesia

\begin{tabular}{cccc}
\hline No & Kategori & Frekuensi Siswa & Persentase \\
\hline 1 & Sangat Tinggi & 3 & $14 \%$ \\
2 & Tinggi & 7 & $32 \%$ \\
3 & Sedang & 6 & $27 \%$ \\
4 & Rendah & 5 & $23 \%$ \\
5 & Sangat Rendah & 1 & $5 \%$ \\
& Jumlah & 22 & $100 \%$ \\
\hline
\end{tabular}

Berdasarkan hasil peresentase standar penilaian yang mengacu pada pedoman PAP skala lima tentang hasil observasi keterampilan berbicara siswa diperoleh hasil $64 \%$ yang termasuk dalam kategori rendah.

Dilihat dari tujuan umumnya, penelitian ini memiliki tujuan untuk mengetahui keterampilan berbicara siswa kelas $\mathrm{V}$ pada mata pelajaran bahasa Indonesia serta faktor-faktor yang memengaruhi keterampilan berbicara siswa kelas V di SD Negeri 4 Temukus. Dari hasil analisis data melalui observasi diketahui bahwa, hasil keseluruhan indikator keterampilan berbicara siswa kelas V di SD Negeri 4 Temukus sudah cukup baik. Berdasarkan data tersebut diketahui persentase hasil observasi keterampilan berbicara adalah $64 \%$. Berdasarkan standar penilaian acuan skala lima, hasilnya termasuk kedalam kategori rendah. Dengan demikian sangat perlu ditingkatkan lagi keterampilan berbicara siswa. Salah satu cara yang dapat dilakukan guru adalah dengan melakukan inovasi pembelajaran yang menarik. Guru hendaknya dapat menggunakan strategi yang tepat dan menarik dalam meningkatkan keterampilan berbicara anak terutama dalam menggunakan kegiatan pembelajaran yang menyenangkan, dengan demikian maka dapat meningkatkan keterampilan berbicara siswa. Pernyataan tersebut juga disampaikan oleh Putra (2016) menyatakan bahwa, Inovasi dalam kegiatan pembelajaran perlu dilakukan agar siswa tidak bosan dengan kegiatan belajarnya di sekolah, serta keterampilan berbicara siswa dapat ditingkatkan. Tidak hanya menciptakan strategi yang tepat dalam pembelajaran tetapi juga membuat suasana belajar yang menyenangkan yang dapat meningkatkan motivasi dan semangat belajar siswa sehingga siswa menjadi lebih aktif dalam pembelajaran misalnya dengan menyediakan media pembelajaran yang menarik yang sesuai dengan materi pembelajaran. Hal tersebut juga disampaikan oleh Arini (2006) menyatakan bahwa, menciptakan suasanan pembelajaran bahasa lisan yang menarik dan menyediakan media pembelajaran merupakan hal yang sangat penting perlu diperhatikan guru. Hal tersebut dapat memotivasi siswa untuk meningkatkan keterampilan berbicara yang dimiliki.

Keterampilan berbicara hanya dapat diperoleh dengan praktik dan banyak berlatih. Berbicara adalah tingkah laku yang harus dipelajari dahulu, kemudian baru bisa dikuasai dengan baik. Siswa yang memiliki keterampilan berbicara yang kurang dapat disebabkan karena kurang berlatih berbicara yang baik dan benar, serta kurangnya interaksi yang terjadi antar siswa, hal ini juga disampaikan oleh Dewi, dkk (2016) mengemukakan bahwa, apabila interaksi yang terjadi antar siswa kurang maka dapat menyebabkan keterampilan berbicara yang dimiliki tidak diasah dengan baik. Padahal dalam pembelajaran bahasa Indonesia, 
keterampilan berbicara sangatlah penting untuk diajarkan kepada siswa. Selain itu, pembelajaran bahasa terjadi secara alamiah dengan adanya suatu interaksi. Berbicara merupakan kegiatan berkomunikasi, yaitu kegiatan pembicaraan yang menyampaikan idenya secara tatap muka kepada orang lain. Keterampilan berbicara cukup penting dalam proses pembelajaran khususnya di sekolah dasar karena dengan keterampilan berbicara siswa dapat menyampaikan pesan secara lisan dan dapat mengungkapkan pikiran atau gagasan yang ada dalam pemikiran siswa.

Dalam kehidupan sehari-hari siswa selalu melakukan dan dihadapkan pada kegiatan berbicara, akan tetapi berbicara pada situasi formal berbeda dengan berbicara pada situasi tidak formal. Hal ini tidak mudah karena dalam situasi yang resmi sering menimbulkan kegugupan sehingga gagasan yang dikemukakan menjadi tidak teratur. Bahasa yang tidak teratur menyebabkan informasi yang disampaikan menjadi kurang efektif dan pendengar sulit memahami isi pembicaraan secara tepat. Misalnya, ketika siswa diminta untuk berbicara didepan kelas untuk melakukan sebuah drama ataupun menyampaikan pendapatnya siswa sering merasa gugup dan kesulitan dalam berbicara di depan umum. Pernyataan tersebut disampaikan juga dalam penelitian yang dilakukan oleh Dharmawan, dkk (2014) bahwa, pada saat proses pembelajaran siswa sering malu dan merasa gugup ketika diminta berbicara atau bercerita di depan kelas. Hal tersebut menunjukan keterampilan berbicara secara praktik masih kurang dikuasai oleh siswa. Berbicara dalam situasi formal memerlukan persiapan dan menuntut keterampilan. Keterampilan berbicara mempunyai peranan penting di dalam kelas maupun di luar kelas. Oleh sebab itu, pembelajaran berbicara perlu diajarkan kepada siswa agar dapat berkomuniksi dengan orang lain dengan bahasa baku yang baik dan benar. Kegiatan berbicara merupakan kegiatan yang sulit dilakukan karena memerkukan persiapan, tidak hanya mengeluarkan bunyi akan tetapi menyususn kalimat yang baik sehingga dapat dipahami. Penjelasan ini sesuai dengan pendapat Mulgrave (dalam Putra, 2016) menyatakan bahwa, aktivitas berbicara tidak sekedar mengeluarkan kata dan bunyi-bunyi, melainkan penyusunan gagasan yang dikembangkan sesuai dengan pendengar atau penyimak, sehingga kegiatan berbicara tidak bisa dikatakan aktivitas yang mudah.

Agar tujuan keterampilan berbicara dapat tercapai dengan baik, sebaiknya siswa memperhatikan faktor-faktor yang memengaruhi keterampilan berbicara dengan teliti. Dengan memperhatikan faktor-faktor tersebut kegiatan berbicara dapat berjalan dengan efektif dan efisien. Keterampilan berbicara tidak dapat dipisahkan dari faktor-faktor yang memengaruhinya, pernyataan tersebut sesuai dengan pendapat Saddhono dan Slamet (2014), yang menyatakan bahwa kegiatan berbicara merupakan aktifitas manusia yang memanfatkan faktor-faktor fisik, psikologis, neurologis, semantik, dan linguistik. Sehingga faktor fisik, psikologis, neurologis, semantik, dan linguistic sangat memengaruhi keterampilan berbicara siswa.

Adapun faktor-faktor yang memengaruhi keterampilan berbicara siswa adalah: Pertama, faktor fisik yaitu alat ucap untuk menghasilkan bunyi bahasa, selain itu kepala, tangan, dan roman muka yang dimanfaatkan dalam berbicara. Bunyi yang dihasilkan oleh alat ucap dan kata-kata harus disusun menurut aturan tertentu agar bermakna. Banyak pembicara kita saksikan berbicara tidak memperhatikan pendengar, tetapi melihat keatas, kesamping, atau menunduk. Akibatnya perhatian pendengar berkurang. Hendaknya diusahakan supaya pendengar merasa terlibat dan diperhatikan. Gerakan-gerakan dan mimik yang tepat dapat pula menunjang keefektifan berbicara, biasanya juga dibantu dengan gerak tangan atau mimik hal ini dapat menghidupkan komunikasi. Tetapi gerak-gerik yang berlebihan akan mengganggu keefektifan berbicara sehingga kesan kurang dipahami. Hal ini juga disampaikan oleh Sujanto (1988), yang menyatakan bahwa, dalam kegiatan berbicara penggunaan 'body language' dilakukan secara wajar dan tepat, karena penggunaan unsur nonverbal secara berlebihan justru akan mengurangi efektifitas komunikasi".

Kedua, faktor psikologis dapat mempengaruhi terhadap kelancaran berbicara. Kelancaran berbicara akan memudahkan pendengaran menangkap isi pembicaraannya. Selain itu berbicara yang terputus-putus bahkan menyelipkan bunyi ee, oo, aa dapat mengganggu penangkapan pendengaran, dan sebalikya pembicara yang terlalu cepat berbicara juga akan menyulitkan pendengar menangkap pembicaraanya. Emosi dan perasaan siswa berpengaruh 
terhadap kelancaran siswa ketika melakukan kegiatan berbicara. Ketika emosi atau perasaan siswa berubah maka berbicara akan mempengaruhi volume suara yang diucapkan, lafal, ekpresi dari pembicaran. Sesuai dengan pendapat tersebut, Arini, dkk (2006) menyatakan bahwa, emosi yang tidak terkendali akan mempengaruhi kualitas suara yang dihasilkan oleh alat ucap sehingga keruntunan pembicaraan akan tidak terkendali serta ekspresi wajah akan berubah pula.

Ketiga, faktor neurologis yaitu jaringan saraf yang menghubungkan otak kecil dengan mulut, telinga dan organ tubuh lain yang ikut dalam aktivitas berbicara. Gangguan saraf-saraf motorik pada anak dapat menyebabkan gangguan perkembangan bicara pada anak dan menyebakan anak menjadi gagap saat berbicara. Hal tersebut sesuai dengan pendapat, Arini, dkk (2006), menyatakan bahwa, apabila salah satu syaraf mengalami gangguan, kegiatan berbicara pun akan terganggu. Kelaian saraf yang dialami siswa dapat menyebabkan siswa sulit untuk berkomunikasi dengan orang lain dan dapat menyebabkan siswa merasa tidak percaya diri dalam berbicara.

Keempat, faktor semantik yang berhubungan dengan makna pembicaraan. Dengan memahami makna pembicaraan maka seseorang yang melakukan kegiatan berbicara akan memahami dengan mudah maksud yang ingin disampaikan. Dengan demikian terjadi komunikasi yang ditandai dengan interaksi antara pembicara dan lawan bicara. Hal tersebut sesuai dengan pendapat, Arini, dkk (2006) menyatakan bahwa, faktor semantik berkaitan dengan makna pembicaraan yang terkandung dalam bunyi-bunyi bahasa harus dapat dipahami oleh kedua belah pihak. Siswa seringkali tidak mengerti dengan makna bicara lawan bicara apabila lawan bicara berbicara terlalu cepat maka menyebabkan kesalahan penafsiran maksud pembicaraan. Semua ini menyangkut kalimat yang diucapkan, pembicara yang menggunakan kalimat efektif akan memudahkan pendengar menangkap pembicaraannya. Dalam kegiatan berbicara agar memiliki tujuan yang jelas, tegas dan gamblang, sehinggga apa yang disampakan pada saat berbicara dapat dengan mudah dipahami pendengar.

Kelima, faktor linguistik yang berkaitan dengan struktur bahasa. Bunyi yang dihasilkan harus disusun menurut aturan tertentu agar bermakna. Jika kata-kata yang disusun itu tidak mengikuti aturan bahasa akan berpengaruh terhadap pemahaman makna oleh lawan bicaranya. Hal tersebut sesuai dengan pendapat Arini, dkk (2006) menyatakan bahwa, pelafalan, pilihan kata, bentuk kata, serta struktur kalimat yang sesuai dengan konteks, lingkungan, dan kaidah yang berlaku perlu diperhatikan manusia agar dapat berkomunikasi dengan sesamanya secara lisan. Seorang pembicara harus membiasakan diri mengucapkan bunyi-bunyi bahasa secara tepat. Pengucapan bunyi bahasa yang kurang tepat, dapat mengalihkan perhatian pendengar, kebosanan dan kurang menyenangkan. Dalam pemilihan kata hendaknya tepat, jelas dan bervariasi. Jelas maksudnya mudah dimengerti oleh pendengar. Kata-kata yang belum dikenal memang membangkitkan rasa ingin tahu, namun akan menghambat kelancaran komunikasi. Selain itu hendaknya pilih kata-kata yang konkret sehingga mudah dipahami pendengar. Dalam pembicaraan formal selalu menuntut persiapan. Tujuannya tidak lain supaya topik yang dipilih betul-betul dikuasai. Pengusaan topik yang baik akan menumbuhkan keberanian dan kelancaran. Hal tersebut sesuai dengan pendapat Saddhono dan Slamet (2014), yang menyatakan bahwa, Penguasaan materi pada saat berbicara dimanfaatkan sebagai pemeperkaya dan bukti penguat materi. Jadi, penguasaan topik ini sangat penting bahkan merupakan faktor utama dalam berbicara. Susunan penuturan kalimat ini sangat besar pengaruhnya terhadap keefektifan penyampaian.

\section{Simpulan dan Saran}

Berdasarkan hasil analisis data dan pembahasan, dapat disimpulkan sebagai berikut. Deskripsi keterampilan berbicara pada mata pelajaran bahasa indonesia siswa kelas $\mathrm{V}$ di SD Negeri 4 Temukus Hasil analisis data dengan observasi keterampilan berbicara siswa diperoleh data rata-rata skor observasi keterampilan berbicara yaitu sebesar 16. Berdasarkan data tersebut diketahui peresentase hasil observasi keterampilan berbicara pada mata 
pelajaran bahasa Indonesia siswa kelas V di SD Negeri 4 Temukus adalah 64\%. Berdasarkan standar penilaian acuan skala lima termasuk kedalam kategori rendah.

Deskripsi faktor-faktor yang memengaruhi keterampilan berbicara pada mata pelajaran bahasa Indonesia siswa kelas V di SD Negeri 4 Temukus. Pertama, faktor fisik yaitu alat ucap untuk menghasilkan bunyi bahasa, seperti kepala, tangan, dan roman muka yang dimanfaatkan dalam berbicara. Kedua, faktor psikologis dapat mempengaruhi terhadap kelancaran berbicara. Ketiga, faktor neurologis yaitu jaringan saraf yang menghubungkan otak kecil dengan mulut, telinga dan organ tubuh lain yang ikut dalam aktivitas berbicara. Keempat, faktor semantik yang berhubungan dengan makna. Kelima, faktor linguistik yang berkaitan dengan struktur bahasa.

Berdasarkan simpulan di atas, maka dapat diajukan saran-saran sebagai berikut. Pertama, Disarankan kepada sekolah dapat melakukan pembinaan dan bimbingan pada siswa yang memiliki keterampilan berbicara yang masih rendah dengan bekerjasama antara guru dengan kepala sekolah untuk bersama-sama meningkatkan keterampilan berbicara siswa yang masih rendah melalui pembelajaran yang menyenangkan,serta membuat programprogram pembinaan keterampilan berbicara siswa. Kedua, guru dalam pembelajaran bahasa Indonesia harus tetap mengolah pembelajaran yang kondusif dan mengarahkan pembelajaran membangun keterampilan berbicara pada mata pelajaran bahasa Indonesia. Ketiga, siswa sebaiknya mempertahankan keterampilan keterampilan berbicara sudah baik dan memperbaiki keterampilan berbicara yang kurang demi meningkatan mutu pendidikan untuk kedepannya. Keempat, peneliti lain untuk dapat dijadikan gambaran, bandingan, atau pedoman dalam melakukan penelitian yang sejenis.

\section{Daftar Rujukan}

Arini, N. W., dkk. 2006. Peningkatan Keterampilan Berbahasa Indonesia Berbasis Kompetensi. Singaraja: Universitas Pendidikan Ganesha Press

Asiah. 2015. "Pendekatan Komunikatif dalam Pembelajaran Bahasa Indonesia untuk Meningkatkan Keterampilan Berbicara Siswa Di Kelas IV SD". E-jurnal Mimbar Sekolah Dasar, Vol 2, p-ISSN 2355-5343, (hal 21-35)

Dewi, dkk. 2006. "Analisis Interaksi Guru dan Siswa dalam Pembelajaran Bahasa Indonesia di Kelas 1 SDN 1 Nawa Kerti”. e-Journal PGSD Universitas Pendidikan Ganesha Jurusan PGSD Vol: 4 No: 1

Dharmawan, dkk. 20014. "Pengaruh Model Pembelajaran Role Playing Terhadap Keterampilan Berbicara Bahasa Indonesia Siswa Kelas V". diakses pada E-Journal Mimbar PGSD Universitas Pendidikan Ganesha, Jurusan PGSD, Vol: 2, No: 1

Haryadi \& Zamzami. 1996. Peningkatan Keterampilan Bahasa Indonesia. Yogyakarta: Departemen Pendidikan dan Kebudayaan.

Hayati, Rachmah. 2017. Peningkatan Kemampuan Berbicara Bahasa Indonesia Dengan Metode Role Playing Pada Materi Ajar Drama Tentang Bela Negara. Prosiding Seminar Nasional Tahunan Fakultas IImu Sosial Universitas Negeri Medan Vol. 1 No. 1 2017, Hal. 482-487

Minirah. 2015. Sistem Pendidikan Di Indonesia: Antara Keinginan Dan Realita . Jurnal Auladuna, Vol. 2 No. 2 Desember 2015: 233-245 
Nurkholis. 2013. Pendidikan Dalam Upaya Memajukan Teknologi . Jurnal Kependidikan, Vol. 1 No. 1 Nopember 2013

Putra, Anggara. 2016. "Metode Role Playing Untuk Meningkatkan Keterampilan Berbicara Siswa Kelas V SDN Wonosari 4". E-Jurnal Pendidikan Guru Sekolah Dasar Edisi 9 Tahun ke-5 2016, (hal 874).

Saddhono \& Slamet 2014. Pembelajaran Keterampilan Berbahasa Indonesia.Yogyakarta: Graha IImu

Sujanto, J. Ch. 1988. Keterampilan Berbahasa Membaca-Menulis-Berbicara untuk Mata Kuliah Dasar Umum Bahasa Indonesia. USA: Columbus

Sutrisno. 2016. Berbagai Pendekatan Dalam Pendidikan Nilai Dan Pendidikan Kewarganegaraan . Jurnal Dimensi Pendidikan dan Pembelajaran Vol.5 Januari 2016

Wardana, dkk. 2014. "Pengaruh Model Pebelajaran Role Playing Terhadap Keterampilan Berbicara Bahasa Indonesia Siswa Kelas V SD Gugus II Kecamatan Karangasem". eJournal Mimbar PGSD Universitas Pendidikan Ganesha Jurusan PGSD, Vol: 2, No: 1.

Wibawa, Yuda, dkk. 2016. "Pengaruh Model Role Playing Berbasis Permainan Tradisional Bali Terhadap Keterampilan Berbicara Pada Mata Pelajaran Bahasa Indonesia Siswa Kelas III". e-Journal PGSD Universitas Pendidikan Ganesha, Jurusan PGSD, Vol: 4, 